\title{
Monoamine oxidase inhibitors: Promising therapeutic agents for Alzheimer's disease (Review)
}

\author{
ZHIYOU CAI \\ Department of Neurology, The Lu'an Affiliated Hospital of Anhui Medical University, \\ Lu'an People's Hospital, Lu'an, Anhui 237005, P.R. China
}

Received July 2, 2013; Accepted February 10, 2014

DOI: $10.3892 / \mathrm{mmr} .2014 .2040$

\begin{abstract}
Activated monoamine oxidase (MAO) has a critical role in the pathogenesis of Alzheimer's disease (AD), including the formation of amyloid plaques from amyloid $\beta$ peptide $(A \beta)$ production and accumulation, formation of neurofibrillary tangles, and cognitive impairment via the destruction of cholinergic neurons and disorder of the cholinergic system. Several studies have indicated that MAO inhibitors improve cognitive deficits and reverse $A \beta$ pathology by modulating proteolytic cleavage of amyloid precursor protein and decreasing $A \beta$ protein fragments. Thus, MAO inhibitors may be considered as promising therapeutic agents for AD.
\end{abstract}

\section{Contents}

1. Introduction

2. Monoamine oxidase (MAO)

3. Involvement of MAO in neurodegeneration

4. Increased MAO activity in the platelets of patients with Alzheimer's disease (AD)?

5. Alterations in MAO levels in the brains of patients with AD

Correspondence to: Dr Zhiyou Cai, Department of Neurology, The Lu'an Affiliated Hospital of Anhui Medical University, Lu'an People's Hospital, 21 Wanxi West Road, Lu'an, Anhui 237005 , P.R. China

E-mail: c0909@hotmail.com

Abbreviations: $\mathrm{A} \beta$, amyloid $\beta$ peptide; $\mathrm{AD}$, Alzheimer's disease; APP, amyloid precursor protein; BACE, $\beta$-site APP cleavage enzyme; ChE, cholinesterase; CNS, central nervous system; CSF, cerebrospinal fluid; DA, dopamine; EP, epinephrine; 5-HT, serotonin; MAO, monoamine oxidase; MAPK, mitogen-activated protein kinase; MMSE, Mini Mental State Examination; NE, norepinephrine; NFT, neurofibrillary tangle; PD, Parkinson's disease; PEA, $\beta$-phenylethylamine; PKC, protein kinase C

Key words: Alzheimer's disease, monoamine oxidase, neurodegeneration, $\beta$-amyloid, tau
6. MAO activation contributes to cognitive impairment in patients with $\mathrm{AD}$

7. Activated MAO contributes to the formation of amyloid plaques

8. Is activated MAO associated with the formation of neurofibrillary tangles?

9. Evidence for the neuroprotective effect of MAO inhibitors in $\mathrm{AD}$

10. Conclusions and outlook

\section{Introduction}

Monoamine oxidase (MAO) catalyzes the oxidative deamination of biogenic and xenobiotic amines and has an important role in the metabolism of neuroactive and vasoactive amines in the central nervous system (CNS) and peripheral tissues. The enzyme preferentially degrades benzylamine and phenylethylamine and targets a wide variety of specific neurotransmitters involved in the primary substrates of MAO in the brain, including epinephrine (EP), norepinephrine (NE), dopamine (DA), serotonin $(5-\mathrm{HT})$, and $\beta$-phenylethylamine (PEA) $(1,2)$. The unique position of MAO in modulating the function of a diverse series of specific neurotransmitters in association with various conditions, including mood disorders (3), anxiety and depression $(4,5)$, schizophrenia (6), attention deficit hyperactivity disorder (7-9), migraine (10), sexual maturation (11) and neurodegenerative diseases (12), has attracted significant attention to the protein as a therapeutic target.

Compelling studies have shown that the involvement of $\mathrm{MAO}$ in $\mathrm{AD}$ and neurodegenerative diseases plays an important role in several key pathophysiological mechanisms $(13,14)$. MAO-B has been proposed as a biomarker, whereas activated MAO-B leads to cognitive dysfunction, destroys cholinergic neurons, causes disorder of the cholinergic system and contributes to the formation of amyloid plaques.

The present review focused on evidence supporting the central role that MAO has in AD pathogenesis, including the formation of amyloid plaques from amyloid $\beta$ peptide $(A \beta)$ production and neurofibrillary tangles (NFTs), and cognitive impairment via the destruction of cholinergic neurons and disorder of the cholinergic system. Studies reporting that MAO inhibitors improve cognitive deficits and reverse $\mathrm{A} \beta$ pathology by modulating proteolytic cleavage of amyloid precursor protein (APP) and decreasing A $\beta$ protein fragments are also 
discussed. Finally, on the basis of current advances in the use of MAO inhibitors for the treatment of $\mathrm{AD}, \mathrm{MAO}$ inhibitors are discussed as a promising therapeutic target for AD.

\section{MAO}

Monoamine oxidase (EC1.4.3.4, a flavin-containing enzyme) is widely distributed in animal tissue and catalyzes the oxidative deamination of primary amines by reaction between dioxygen and $\mathrm{R}-\mathrm{CH}_{2}-\mathrm{NH}_{2}$ to form R-CHO, $\mathrm{NH}_{3}$ and $\mathrm{H}_{2} \mathrm{O}_{2}$ (Fig. 1). $\mathrm{MAO}$ removes an amine group by catalyzing the oxidative deamination of monoamines, resulting in the corresponding aldehyde and ammonia. MAO exists as two isozymes in humans: MAO-A and MAO-B, which are distinct due to different amino acid sequences, three-dimensional structures, distributions in organs and tissue, inhibitor sensitivities and substrate specificity. The two isozymes are found in and outside the CNS.

With regard to the functions of MAO, a wide range of pathophysiological roles have been suggested, including the regulation of cardiac function and blood pressure (15), as well as involvement in a number of psychiatric and neurological disorders, including mood, depression, schizophrenia, migraine, sexual maturation and neurodegenerative diseases. The notable role of MAO is in the regulation of neurotransmitter activity, since the primary substrates of MAO in the brain are specific neurotransmitters, including EP, NE, DA, 5-HT and PEA.

\section{Involvement of MAO in neurodegeneration}

An increasing number of studies have demonstrated the involvement of MAO in neurodegenerative diseases, including Parkinson's disease (PD) $(16,17)$, AD $(18,19)$, Lewy body diseases with dementia (20) and depression (17,21). MAO is involved in neurodegeneration via oxidative stress, which has a central role in neurodegenerative diseases (22). Other mechanisms have been identified, including neuroinflammation (23), triggering of apoptosis $(18,24)$, failure of aggregated-protein clearance (25-27) and glial activation (28) by MAO.

$\mathrm{PD}$ is the second most common age-related neurodegenerative disease after $\mathrm{AD}$, and is characterized by progressive loss of dopaminergic neurons in the substantia nigra, depletion of DA in the striatum, abnormal mitochondrial and proteasomal functions and accumulation of $\alpha$-synuclein $(29,30)$. It has been suggested that the increased turnover of DA and dopaminergic neurodegeneration are associated with oxidative stress derived from an increased production of hydrogen peroxide, which is formed during the oxidative deamination of DA by MAO (29,31). A recent study showed that activated MAO induces $\alpha$-synuclein aggregation, which may be associated with early Parkinsonism and dopaminergic neurodegeneration in the substantia nigra in SMAD family member 3-null mice (32). The evidence that either inhibition or iron chelation of MAO exerts neuroprotective effects strongly indicates that $\mathrm{MAO}$ is a major component in the process of $\mathrm{PD}$ neurodegeneration under oxidative stress (17). In PD, dopaminergic cell death in the substantia nigra is linked to a marked glutathione decrease and mitochondrial dysfunction (24). MAO in the mitochondrial outer membrane induces oxidative stress resulting in neuronal degeneration through the production of hydrogen peroxide by

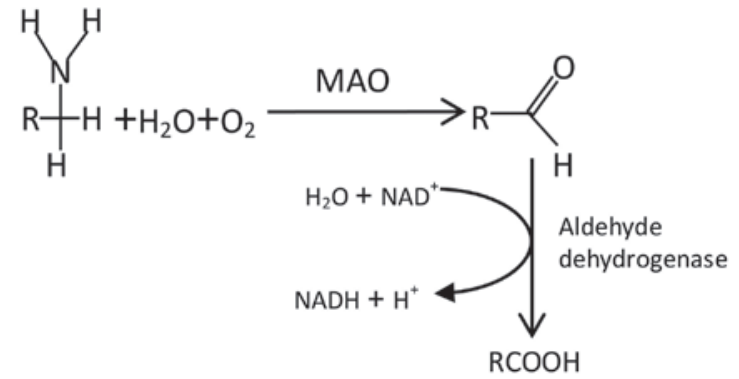

Figure 1. General reaction catalyzed by MAO. The reaction of a base ( $R$, arbitrary group) with one ammonia and two hydrogen components plus water and oxygen, catalyzed by MAO, generates the aldehyde, ammonia and $\mathrm{H}_{2} \mathrm{O}_{2}$. MAO, monoamine oxidase.

oxidation of monoamine substrates $(18,33,34)$. These results suggest that MAO is involved in the neurodegenerative pathogenesis of PD that manifests as increased oxidative stress and a major impairment of the glutathione pathway.

Studies have shown that activated MAO in the brains of patients with $\mathrm{AD}$ is a biomarker for $\mathrm{AD}$ (35-37). This was demonstrated by $\left[{ }^{11} \mathrm{C}\right]$-L-deprenyl using whole hemisphere autoradiography $(38-40)$, epidemiology $(41,42)$, morphology (43), as well as single-photon emission computed tomography (44). Such studies demonstrated that: i) MAO activity in platelets was significantly increased in patients with $\mathrm{AD}$ and acted as a marker of behavioral characteristics in dementia disorders $(41,45-48)$; ii) there were early and persistent alterations in MAO-A and -B in the brains of patients with $\mathrm{AD}$ (49); iii) activated MAO led to cognitive dysfunction (50); iv) activated MAO destroyed cholinergic neurons and caused disorders of the cholinergic system (51); v) activated MAO contributed to the formation of amyloid plaques $(13,14)$ and vi) activated $\mathrm{MAO}$ was associated with the formation of NFTs.

Pharmacological studies have demonstrated that MAO inhibitors exert neuroprotective effects in patients with $\operatorname{AD}(21,52,53)$ through the following mechanisms: Improvement of cognitive impairment $(50,54,55)$; antioxidant and enhancement of iron chelating activities (56-59); regulation of APP and A $\beta$ expression processing $(56,60)$, involving the activation of certain signaling pathways, including the p42/44 mitogen-activated protein kinase (MAPK) and protein kinase C (PKC) signaling pathways (61); and inhibition of cholinesterase (ChE) activity (62-64).

\section{Increased MAO activity in the platelets of patients with AD?}

MAO activity has previously been found to be high in the brain and in platelets in patients with $\mathrm{AD}$, while the activity of MAO-B in the brain increases with age due to an increased concentration of MAO-B (35). Compared with age- and gender-matched controls, MAO activity in platelets was significantly higher in patients with dementia of the Alzheimer type, and the MAO-B but not the MAO-A activity was significantly higher in the hippocampus and cortex of the gyrus cinguli in the $\mathrm{AD}$ group (65). In the aging controls, MAO-B activity in the brain was positively correlated with age $(35,65)$.

Studies on the association between platelet MAO-B activity, clinical features and cerebrospinal fluid (CSF) monoamine 
metabolites have demonstrated the importance of MAO-B activity in platelets as a biological marker of AD (47,66). An increased activity of this enzyme may constitute a marker for vulnerability towards behavioral disturbance (47). According to a Mini Mental State Examination (MMSE) of three groups with 23 patients in the early (MMSE score of 19-24), 23 patients in the middle (MMSE score of 10-18) and 28 patients in the late (MMSE score of 0-9) phases of AD, as well as 49 age-matched healthy females, significant correlations between MMSE scores and MAO-B activity and age were identified, suggesting that these markers may indicate the severity and/or clinical progress of $\operatorname{AD}(42,45)$.

However, several studies have indicated that MAO activity in platelets is not associated with the pathogenesis of AD (67-69). The MMSE indicated that no correlation was present between platelet MAO-B activity and the cognitive score in patients with AD (54). No significant differences were found in the levels of the amine metabolites homovanillic acid and methoxyhydroxyphenylglycol in the CSF of drug-free patients with AD as compared with those in a group of controls, showing that AD was not associated with changes in central catecholamine metabolism and increased platelet MAO activity (70). In view of MAO being involved in the metabolic inactivation of several monoaminergic neurotransmitters, including 5-HT, melatonin, NE and EP $(21,70,71)$, a complex dysfunction in the MAO system is likely to be present in AD $(48,69)$. Furthermore, MAO activity may be used to distinguish patients with $\mathrm{AD}$ due to the existence of a biologically-based behavioral subtype of AD (72). Different results may be obtained for $\mathrm{MAO}$ in $\mathrm{AD}$ for different species and in different experimental settings.

\section{Alterations in MAO levels in the brains of patients with AD}

Early and persistent alterations in MAO levels in the brains of patients with AD have been demonstrated by several studies that show the role of the hyperoxidation phenomena by MAO in the mechanism of neuronal cell death in AD. The oxidative degradation catalyzed by MAO produces free radicals and may thus be involved in the neurodegenerative process $(73,74)$. In the $\mathrm{CNS}$, the MAO-A isoform appears to be present mainly in catecholaminergic neurons, whereas the MAO-B form is primarily located in the glia and in serotonergic neurons (49). Radioenzymatic assay at brain autopsy revealed that the changes in MAO-A and -B in the prefrontal cortex occur in the early stages of $\mathrm{AD}$ and remain relatively constant as the disease progresses (49). It has also been revealed that MAO-A and -B protein and/or mRNA levels are increased in several brain areas, including the frontal lobe of the neocortex, as well as the parietal, occipital, temporal and frontal cortex (37,75-77). This indicates that the mechanism in MAO enzymes may be transcriptional or post-transcriptional and may be responsible for the increase in protein activity as well as important for the progression of AD.

Although the occurrence of activated MAO-B in the brains of patients with $\mathrm{AD}$ has been evidenced, it appears that MAO-A has a different appearance in different parts of the brains of patients with AD. Immunostaining showed that the activity of MAO-B was significantly increased in the cortical areas and in the hippocampus in AD, reflecting the underlying cell loss and substantial gliosis in these areas of the brain (76), while MAO-A was increased in the hypothalamus and frontal pole (37). Furthermore, MAO-A activity appears to be lower in the locus ceruleus in patients with $\mathrm{AD}$, and is accompanied by an $\sim 80 \%$ decrease in the number of neurons (78), revealing that activated MAO-A in neurons is involved in the pathology of this disease as a predisposing factor. In comparison, increased MAO-A activity appeared more significant in the glia of patients with AD (79). Thus, the changes in MAO-A levels in patients with AD appear to have multiple mechanisms.

\section{MAO activation contributes to cognitive impairment in patients with $\mathrm{AD}$}

Numerous studies have shown that monoamine neurotransmitter systems have a determining role in cognition at the biomolecular level, including memory $(80)$, orientation $(81,82)$, attention (83), paranoid thinking (84), as well as behavior and emotion $(81,85)$. MAO can disturb the balance of certain other brain chemical neurotransmitters, including glutamatergic action, ChE, acetylcholinesterase, 5-HT and NE (86-91), and, therefore, causes symptoms of cognitive impairment. MAO-A and $-\mathrm{B}$ exhibit different substrate specificity and inhibitor selectivity. Extensive studies have revealed that MAO-A preferentially acts on 5-HT and NE (92-94) and MAO-B acts positively on 2-phenylethylamine and benzylamine $(95,96)$. $\mathrm{NE}$ has a determinant role in executive function, regulating cognition, motivation and intellect, which are fundamental in social relationships (97). Activated MAO is a contributing factor in neuronal NE pathways and highlights the specific role of NE in the symptoms of disordered executive function (97). Activated MAO is also a detrimental element for the function of the cholinergic system, which is mostly associated with memory and emotion $(51,86,88)$. A recent population-based study showed a significant interaction between MAO-A and catechol-O-methyltransferase genotypes, such that increased prefrontal catecholamine availability was associated with an enhanced working memory (80). Although there are no reports on the direct association between MAO and the aforementioned neurotransmitter systems in AD, numerous studies suggest that activated MAO is indirectly involved in the close association between cognitive impairment and several neurotransmitter systems in AD (98-100). It is well accepted that oxidative stress (associated with MAO) contributes to the disturbance of aforementioned neurotransmitters, including $\mathrm{NE}$ and the cholinergic system, which have a critical role in the cognitive impairment in AD (100-103). Considering that neuroinflammation is a key element in cognitive impairment and an intermediate for oxidative stress (104-107), MAO may act as a proinflammatory mediator, which causes cognitive impairment in AD. Elevated monoamine levels in the brain resulting from MAO induce changes in other neurotransmitter systems and lead to cognitive impairment.

\section{Activated MAO contributes to the formation of amyloid plaques}

The amyloid hypothesis was proposed $>100$ years before it was demonstrated that the amyloid plaque, a pathological 


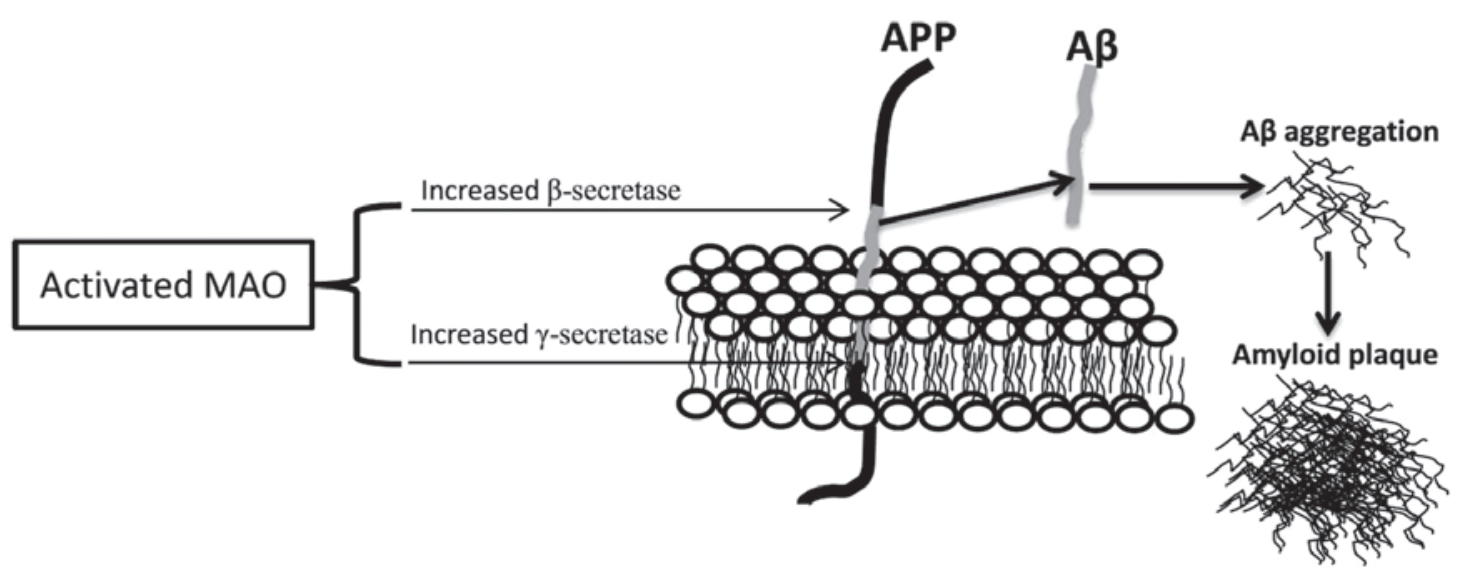

Figure 2. A $\beta$ generation through modulation of APP processing by activated MAO. Activated MAO increases the expression of $\beta$-secretase and $\gamma$-secretase, improves $A \beta$ generation and contributes to the formation of amyloid plaques. $A \beta$, amyloid $\beta$ peptide; MAO, monoamine oxidase; APP, amyloid precursor protein.

characteristic of $\mathrm{AD}$, is induced by the generation and deposition of $A \beta$ (108). $A \beta$ is the root cause of the pathogenesis of $\mathrm{AD}$, and various mechanisms of neuronal degeneration have been proposed, including the formation of free radicals triggered by $A \beta$, the interaction between oxidative stress and the production of $A \beta$, the association between inflammatory processes and $A \beta(109,110)$, as well as genetic factors and apoptosis associated with the generation of $\mathrm{A} \beta$.

Studies on the pathogenesis of AD have revealed that oxidative damage is present in $\mathrm{AD}$, which is the progressive neurodegenerative disease of ageing. Increased oxidative stress in patients with $\mathrm{AD}$ contributes to $\mathrm{A} \beta$ generation and the formation of amyloid plaques. It has been established that MAO, a marker of oxidative stress, is linked to the production of reactive oxygen species and other molecules that cause oxidative stress, which results in neuronal damage and neurodegeneration, including $\mathrm{AD}$, indicating that excessive MAO activity contributes to neurodegeneration in $\mathrm{AD}(62,111-113)$. Molecular biology studies have shown the critical role of $A \beta$ generation through the modulation of APP processing by MAO (60,61,114,115) (Fig. 2).

$A \beta$ generation is the result of two sequential cleavages of APP by $\beta$-secretase ( $\beta$-site APP cleavage enzyme, BACE) and $\gamma$-secretase. Extracellular cleavage by $\beta$-secretase is the first step of $A \beta$ production, between the Met671 and Asp672 residues of APP, which results in a soluble extracellular fragment and a cell membrane-bound fragment (C99). C99 is then further cleaved by $\gamma$-secretase within the hydrophobic transmembrane domain at either Val711 or Ile713, finally releasing $A \beta$ and the intracellular domain of APP. The non-amyloidogenic pathway, in which APP is sequentially cleaved by $\alpha$ - and $\gamma$-secretase, may prevent the production of $A \beta(116,117)$. Several studies have reported that propargylamine-containing compounds, including ladostigil and M30, irreversible and selective MAO-B inhibitors, act as modulators of the proteolytic cleavage of APP via activation of the p42/44MAPK and PKC signaling pathways $(61,118-120)$. It was also demonstrated that M30 effectively inhibited $A \beta$ accumulation and tau phosphorylation in APP/presenilin 1 mice, where it markedly downregulated the levels of phosphorylated cyclin-dependent kinase 5 and increased PKC and glycogen synthase kinase- $3 \beta$ phosphory- lation (121). Furthermore, deprenyl, an irreversible MAO-B inhibitor, was able to increase processing of APP through the non-amyloidogenic pathway via MAPK and PKC-dependent signaling pathways, and increase $\alpha$-secretase activity in a dose-dependent manner in vitro through the involvement of protein trafficking (122). In A $\beta$-injected mice it was found that co-administration of donepezil with selegiline significantly alleviated cognitive impairment, indicating a synergistic cognition-improving effect by MAO inhibitors (123).

Substantial basic biomolecular and clinical studies suggest that neuroinflammation, with overexpression of cytokines and inflammatory mediators, is centrally involved in the pathogenesis of AD (124-126). One notable feature of the pathophysiology of the brains of patients with AD is that oxidative stress can induce an active, self-perpetuating cycle of chronic neuroinflammation, which further promotes oxidative stress and contributes to irreversible neuronal dysfunction and cell death (127). The interaction between oxidative stress and neuroinflammation is an important contributing factor to $A \beta$ generation. Furthermore, oxidative stress and neuroinflammation are critical in the pathogenic cascade of neurodegeneration in $\mathrm{AD}$, suggesting that therapeutic efforts aimed at these two mechanisms may be beneficial. It has been evidenced that several MAO inhibitors restrain the production of $A \beta$ by inhibiting neuroinflammation, such as the inhibition of nuclear factor $\mathrm{kB}$ activity, the downregulation of the expression of interleukin $1 \beta$ and tumor necrosis factor $\alpha$, and the limitation of glial activation $(38,128,129)$.

\section{Is activated MAO associated with the formation of NFTs?}

NFTs are well known as a primary pathological marker of AD. It has been indicated that oxidative stress not only is a major factor in the early stages of $\mathrm{AD}$, but also contributes to the formation of NFTs via the aggregation of hyperphosphorylated tau protein. Activated MAO, a trigger for oxidative stress, produces reactive oxygen species in mitochondria and benefits the pathogenesis of neurodegeneration (130). Theoretically, it is possible that activated MAO is associated with the forma- 
Table I. Evidence for the neuroprotective effect of MAO inhibitors in Alzheimer's disease.

\begin{tabular}{|c|c|c|c|}
\hline Inhibitor & Neuroprotective mechanism & Preclinical or clinical stage & References \\
\hline Rasagiline & $\begin{array}{l}\text { Novel multitarget iron chelators with AChE. } \\
\text { Regulates APP and A } \beta \text { expression processing, } \\
\text { activates pro-survival signaling pathways and } \\
\text { regulates cell cycle }\end{array}$ & $\begin{array}{l}\text { A phase II clinical study; } \\
\text { in vivo and in vitro }\end{array}$ & $(56,57,62,131-133)$ \\
\hline Ladostigil & $\begin{array}{l}\text { Dual acetylcholine-butyrylcholineesterase; a } \\
\text { novel MAO and AChE inhibitor. Regulates } \\
\text { APP translation and processing }\end{array}$ & $\begin{array}{l}\text { A phase IIb clinical study; } \\
\text { in vivo and in vitro }\end{array}$ & $(28,114,134,135)$ \\
\hline $\begin{array}{l}\text { Selegiline } \\
\text { (L-deprenyl) }\end{array}$ & $\begin{array}{l}\text { Antioxidant, selective inhibitor of MAO-B. } \\
\text { Modulates proteolytic cleavage of APP, } \\
\text { involves mitogen-activated protein kinase and } \\
\text { activates PKC, inhibits A } \beta \text { production }\end{array}$ & $\begin{array}{l}\text { The Cochrane Dementia and } \\
\text { Cognitive Impairment Group } \\
\text { Register of Clinical Trials; } \\
\text { Unconfounded, double-blind, } \\
\text { randomised trials }\end{array}$ & $(61,136-141)$ \\
\hline M-30 & $\begin{array}{l}\text { Iron chelator-MAO inhibitor drug; modulates } \\
\text { proteolytic cleavage of APP }\end{array}$ & $\begin{array}{l}\text { In vivo and in vitro; in clinical } \\
\text { trials }\end{array}$ & $(15,61,112,142)$ \\
\hline
\end{tabular}

A $\beta$, amyloid $\beta$ peptide; MAO, monoamine oxidase; PKC, protein kinase C; APP, amyloid precursor protein; AChE, acetylcholinesterase.

tion of NFTs (131). However, it remains to be elucidated whether activated MAO directly leads to the aggregation of hyperphosphorylated tau protein and the formation of NFTs since, to the best of our knowledge, it has not been reported.

\section{Evidence for the neuroprotective effect of MAO inhibitors in AD}

An increasing number of molecular biology and pharmacology studies have shown the neuroprotective effects of MAO inhibitors on the prevention and treatment of AD $(21,52,53)$ (Table I) $(15,56,57,61,62,112,114,131-144)$. The main neuroprotective mechanisms of MAO inhibitors in AD include the following: i) Improvement of cognitive impairment $(50,54,55)$, where MAO inhibitors correct chemical imbalances in the brain; ii) antioxidant activities and enhancement of iron-chelating activities (56-59), where chelators can modulate $\mathrm{A} \beta$ accumulation, protect against tau hyperphosphorylation and block metal-associated oxidative stress, thereby holding considerable promise as effective anti-AD drugs $(145,146)$; iii) regulation of APP and $A \beta$ expression processing $(56,60)$, for example ladostigil (TV3326), a selective MAO-B inhibitor, which regulates APP translation and processing (114); iv) the selective MAO inhibitors selegiline and rasagiline have been proven to possess neuroprotective activities in cell cultures and animal models of neurodegenerative diseases through the activation of certain signaling pathways, including p42/44 MAPK and PKC (61); v) inhibition of ChE activity by the MAO inhibitor rasagiline (62-64), with MAO inhibitors also affecting other chemicals throughout the body and acting by correcting chemical imbalances in the brain.

Laboratory and clinical studies have evidenced that the MAO inhibitors are a potential therapeutic approach for the treatment of AD. Certain novel pyrazole derivatives as dual MAO inhibitors and anti-inflammatory analgesics (148) are also a novel therapeutic approach in AD. Thus, selective MAO inhibitors may be a promising alternative for AD therapy. An enhanced understanding of MAO inhibitors may result in improved treatment of AD in the future $(149,150)$.

\section{Conclusions and outlook}

Activated MAO-B in the brains of patients with AD is a biomarker for AD. Studies have shown that activated MAO contributes to cognitive dysfunction, destroys cholinergic neurons, causes disorder of the cholinergic system and leads to the formation of amyloid plaques and NFTs.

Numerous studies support the involvement of activated MAO in AD. Thus, drugs used to inhibit activated MAO, including rasagiline, ladostigil and selegiline, may provide neuroprotection against AD by improving cognitive impairment, modulating the proteolytic cleavage of APP and decreasing levels of $A \beta$ protein fragments that accumulate in the brain. Although clinical trials involving the MAO-deactivating drugs have been largely conducted, numerous questions remain to be answered regarding the clinical trials of the drugs. As MAO is well known for its effects on neurotransmitter substance and MAO inhibitors are infamous for their numerous drug interactions, these drugs may produce a number of unwanted side effects. It remains to be elucidated whether MAO inhibitors have severe long-term effects via the inhibition of chemicals that break down 5-HT, NE and DA, which may lead to intolerably high levels of any of these neurochemicals. MAO inhibitors may be particularly harmful when taken with certain foods, beverages and medicines. Future clinical studies on MAO inhibitors for the treatment of $\mathrm{AD}$ are required, and these may provide further insights into the mechanism of action of antioxidants as therapeutic agents for $\mathrm{AD}$.

\section{Acknowledgements}

The present study was supported by a grant from the Provincial Nature Science Foundation of Anhui (1308085MH158) to Dr Zhiyou Cai. 


\section{References}

1. Said UZ, Saada HN, Abd-Alla MS, Elsayed ME and Amin AM Hesperidin attenuates brain biochemical changes of irradiated rats. Int J Radiat Biol 88: 613-618, 2012

2. Bodkin JA, Cohen BM, Salomon MS, Cannon SE, Zornberg GL and Cole JO: Treatment of negative symptoms in schizophrenia and schizoaffective disorder by selegiline augmentation of antipsychotic medication. A pilot study examining the role of dopamine. J Nerv Ment Dis 184: 295-301, 1996.

3. Dunleavy DL: Mood and sleep changes with monoamine-oxidase inhibitors. Proc R Soc Med 66: 951, 1973.

4. Shabbir F, Patel A, Mattison C, Bose S, Krishnamohan R, Sweeney E, Sandhu S, Nel W, Rais A, Sandhu R, Ngu N and Sharma S: Effect of diet on serotonergic neurotransmission in depression. Neurochem Int 62: 324-329, 2013.

5. Merikangas KR and Merikangas JR: Combination monoamine oxidase inhibitor and beta-blocker treatment of migraine, with anxiety and depression. Biol Psychiatry 38: 603-610, 1995.

6. Samson JA, Gurrera RJ, Nisenson L and Schildkraut JJ: Platelet monoamine oxidase activity and deficit syndrome schizophrenia. Psychiatry Res 56: 25-31, 1995.

7. Lawson DC, Turic D, Langley K, Pay HM, Govan CF, Norton N, Hamshere ML, Owen MJ, O'Donovan MC and Thapar A: Association analysis of monoamine oxidase $\mathrm{A}$ and attention deficit hyperactivity disorder. Am J Med Genet B Neuropsychiatr Genet 116B: 84-89, 2003.

8. Wargelius HL, Malmberg K, Larsson JO and Oreland L: Associations of MAOA-VNTR or 5HTT-LPR alleles with attention-deficit hyperactivity disorder symptoms are moderated by platelet monoamine oxidase B activity. Psychiatr Genet 22: 42-45, 2012.

9. Nedic G, Pivac N, Hercigonja DK, Jovancevic M, Curkovic KD and Muck-Seler D: Platelet monoamine oxidase activity in children with attention-deficit/hyperactivity disorder. Psychiatry Res 175: 252-255, 2010.

10. Marziniak M, Mössner R, Benninghoff J, Syagailo YV, Lesch KP and Sommer C: Association analysis of the functional monoamine oxidase A gene promotor polymorphism in migraine. J Neural Transm 111: 603-609, 2004.

11. Moreno ML, Villanúa MA and Esquifino AI: Serum prolactin and luteinizing hormone levels and the activities of hypothalamic monoamine oxidase A and B and phenylethanolamine-N-methyl transferase are changed during sexual maturation in male rats treated neonatally with melatonin. J Pineal Res 13: 167-1731, 1992.

12. Youdim MB, Fridkin M and Zheng H: Novel bifunctional drugs targeting monoamine oxidase inhibition and iron chelation as an approach to neuroprotection in Parkinson's disease and other neurodegenerative diseases. J Neural Transm 111: 1455-1471, 2004.

13. Huang L, Lu C, Sun Y, Mao F, Luo Z, Su T, Jiang H, Shan W and Li X: Multitarget-directed benzylideneindanone derivatives: anti- $\beta$-amyloid $(\mathrm{A} \beta)$ aggregation, antioxidant, metal chelation, and monoamine oxidase $\mathrm{B}$ (MAO-B) inhibition properties against Alzheimer's disease. J Med Chem 55: 8483-8492, 2012.

14. Zheng H, Fridkin M and Youdim MB: From antioxidant chelators to site-activated multi-target chelators targeting hypoxia inducing factor, beta-amyloid, acetylcholinesterase and monoamine oxidase A/B. Mini Rev Med Chem 12: 364-370, 2012.

15. Gal S, Abassi ZA and Youdim MB: Limited potentiation of blood pressure in response to oral tyramine by the anti-Parkinson brain selective multifunctional monoamine oxidase-AB inhibitor, M30. Neurotox Res 18: 143-150, 2010.

16. Youdim MB and Lavie L: Selective MAO-A and B inhibitors, radical scavengers and nitric oxide synthase inhibitors in Parkinson's disease. Life Sci 55: 2077-2082, 1994.

17. Youdim MB and Bakhle YS: Monoamine oxidase: isoforms and inhibitors in Parkinson's disease and depressive illness. Br J Pharmacol 147 (Suppl 1): S287-S296, 2006.

18. Naoi M, Maruyama W, Akao Y, Yi H and Yamaoka Y: Involvement of type A monoamine oxidase in neurodegeneration: regulation of mitochondrial signaling leading to cell death or neuroprotection. J Neural Transm Suppl: 67-77, 2006.

19. Zheng H, Youdim MB and Fridkin M: Site-activated chelators targeting acetylcholinesterase and monoamine oxidase for Alzheimer's therapy. ACS Chem Biol 5: 603-610, 2010.

20. Cummings JL: Lewy body diseases with dementia: pathophysiology and treatment. Brain Cogn 28: 266-280, 1995.
21. Drozak J and Kozłowski M: Monoamine oxidase as a target for drug action. Postepy Hig Med Dosw (Online) 60: 498-515, 2006 (In Polish)

22. Siddiqui A, Mallajosyula JK, Rane A and Andersen JK: Ability to delay neuropathological events associated with astrocytic MAO-B increase in a Parkinsonian mouse model: implications for early intervention on disease progression. Neurobiol Dis 43: 527-532, 2011.

23. Bielecka AM, Paul-Samojedny $M$ and Obuchowicz E: Moclobemide exerts anti-inflammatory effect in lipopolysaccharide-activated primary mixed glial cell culture. Naunyn Schmiedebergs Arch Pharmacol 382: 409-417, 2010.

24. Merad-Boudia M, Nicole A, Santiard-Baron D, Saillé C and Ceballos-Picot I: Mitochondrial impairment as an early event in the process of apoptosis induced by glutathione depletion in neuronal cells: relevance to Parkinson's disease. Biochem Pharmacol 56: 645-655, 1998.

25. Hüll M, Berger M and Heneka M: Disease-modifying therapies in Alzheimer's disease: how far have we come? Drugs 66: 2075-2093, 2006.

26. Rodríguez S, Ito T,He XJ, Uchida K and Nakayama H: Resistance of the golden hamster to 1-methyl-4-phenyl-1,2,3,6-tetrahydropyridine (MPTP)-neurotoxicity is not only related with low levels of cerebral monoamine oxidase-B. Exp Toxicol Pathol 65: 127-133, 2013.

27. Konradi C, Riederer P, Jellinger K and Denney R: Cellular action of MAO inhibitors. J Neural Transm Suppl 25: 15-25, 1987.

28. Weinstock M, Luques L, Poltyrev T, Bejar C and Shoham S: Ladostigil prevents age-related glial activation and spatial memory deficits in rats. Neurobiol Aging 32: 1069-1078, 2011.

29. Spina MB and Cohen G: Dopamine turnover and glutathione oxidation: implications for Parkinson disease. Proc Natl Acad Sci USA 86: 1398-1400, 1989.

30. Farooqui T and Farooqui AA: Lipid-mediated oxidative stress and inflammation in the pathogenesis of Parkinson's disease. Parkinsons Dis 2011: 247467, 2011.

31. Loeffler DA, DeMaggio AJ, Juneau PL, Havaich MK and LeWitt PA: Effects of enhanced striatal dopamine turnover in vivo on glutathione oxidation. Clin Neuropharmacol 17: 370-379, 1994.

32. Tapia-González S, Giráldez-Pérez RM, Cuartero MI, Casarejos MJ, Mena MÁ, Wang XF and Sánchez-Capelo A: Dopamine and $\alpha$-synuclein dysfunction in Smad3 null mice. Mol Neurodegener 6: 72, 2011

33. Oberpichler-Schwenk H: Rasagiline. A new monoamine oxidase $\mathrm{b}$ inhibitor for Parkinson treatment. Med Monatsschr Pharm 28: 224-227, 2005 (In German).

34. Chen JJ and Wilkinson JR: The monoamine oxidase type B inhibitor rasagiline in the treatment of Parkinson disease: is tyramine a challenge? J Clin Pharmacol 52: 620-628, 2012.

35. Oreland L and Gottfries CG: Brain and brain monoamine oxidase in aging and in dementia of Alzheimer's type. Prog Neuropsychopharmacol Biol Psychiatry 10: 533-540, 1986.

36. Sherif F, Gottfries CG, Alafuzoff I and Oreland L: Brain gamma-aminobutyrate aminotransferase (GABA-T) and monoamine oxidase (MAO) in patients with Alzheimer's disease. J Neural Transm Park Dis Dement Sect 4: 227-240, 1992.

37. Sparks DL, Woeltz VM and Markesbery WR: Alterations in brain monoamine oxidase activity in aging, Alzheimer's disease, and Pick's disease. Arch Neurol 48: 718-721, 1991.

38. Gulyás B, Pavlova E, Kása P, Gulya K, Bakota L, Várszegi S, Keller E, Horváth MC, Nag S, Hermecz I, Magyar K and Halldin C: Activated MAO-B in the brain of Alzheimer patients, demonstrated by [11C]-L-deprenyl using whole hemisphere autoradiography. Neurochem Int 58: 60-68, 2011.

39. Hirvonen J, Kailajärvi M, Haltia T, Koskimies S, Någren K, Virsu P, Oikonen V, Sipilä H, Ruokoniemi P, Virtanen K, Scheinin M and Rinne JO: Assessment of MAO-B occupancy in the brain with PET and [11C]-L-deprenyl-D2: a dose-finding study with a novel MAO-B inhibitor, EVT 301. Clin Pharmacol Ther 85: 506-512, 2009.

40. Jossan SS, Gillberg PG, Karlsson I, Gottfries CG and Oreland L: Visualization of brain monoamine oxidase B (MAO-B) in dementia of Alzheimer's type by means of large cryosection autoradiography: a pilot study. J Neural Transm Suppl 32: 61-65, 1990.

41. Fischer P, Götz ME, Ellinger B, Streifler M, Riederer P and Danielczyk W: Platelet monoamine oxidase B activity and vitamin B12 in dementia. Biol Psychiatry 35: 772-774, 1994. 
42. Muck-Seler D, Presecki P, Mimica N, Mustapic M, Pivac N, Babic A, Nedic G and Folnegovic-Smalc V: Platelet serotonin concentration and monoamine oxidase type B activity in female patients in early, middle and late phase of Alzheimer's disease. Prog Neuropsychopharmacol Biol Psychiatry 33: 1226-1231, 2009

43. Riederer $\mathrm{P}$ and Jellinger K: Morphological and biochemical changes in the aging brain: pathophysiological and possible therapeutic consequences. Exp Brain Res (Suppl 5): 158-166, 1982.

44. Battistin L, Rigo A, Bracco F, Dam M and Pizzolato G: Metabolic aspects of aging brain and related disorders. Gerontology 33 253-258, 1987.

45. Mimica N, Mück-Seler D, Pivac N, Mustapić M, Dezeljin M, Stipcević T, Presecki P, Radonić E and Folnegović-Smalc V: Platelet serotonin and monoamine oxidase in Alzheimer's disease with psychotic features. Coll Antropol 32 (Suppl 1): $119-122,2008$

46. Götz ME, Fischer P, Gsell W, Riederer P, Streifler M, Simanyi M, Müller F and Danielczyk W: Platelet monoamine oxidase B activity in dementia. A 4-year follow-up. Dement Geriatr Cogn Disord 9: 74-77, 1998

47. Parnetti L, Reboldi GP, Santucci C, Santucci A, Gaiti A, Brunetti M, Cecchetti R and Senin U: Platelet MAO-B activity as a marker of behavioural characteristics in dementia disorders. Aging (Milano) 6: 201-207, 1994.

48. Bonuccelli U, Piccini P, Marazziti D, Cassano GB and Muratorio A: Increased platelet $3 \mathrm{H}$-imipramine binding and monoamine oxidase B activity in Alzheimer's disease. J Neural Transm Park Dis Dement Sect 2: 139-147, 1990.

49. Kennedy BP, Ziegler MG, Alford M, Hansen LA, Thal LJ and Masliah E: Early and persistent alterations in prefrontal cortex MAO A and B in Alzheimer's disease. J Neural Transm 110 : 789-801, 2003

50. Delumeau JC, Bentué-Ferrer D, Gandon JM, Amrein R, Belliard S and Allain H: Monoamine oxidase inhibitors, cognitive functions and neurodegenerative diseases. J Neural Transm Suppl 41: 259-266, 1994

51. Grailhe R, Cardona A, Even N, Seif I, Changeux JP and Cloëz-Tayarani I: Regional changes in the cholinergic system in mice lacking monoamine oxidase A. Brain Res Bull 78: 283-289, 2009.

52. Riederer P, Danielczyk W and Grünblatt E: Monoamine oxidase-B inhibition in Alzheimer's disease. Neurotoxicology 25 271-277, 2004

53. Thomas T: Monoamine oxidase-B inhibitors in the treatment of Alzheimer's disease. Neurobiol Aging 21: 343-348, 2000.

54. Soto J, Ulibarri I, Jauregui JV, Ballesteros J and Meana JJ: Dissociation between I2-imidazoline receptors and MAO-B activity in platelets of patients with Alzheimer's type dementia. J Psychiatr Res 33: 251-257, 1999.

55. Finali G, Piccirilli M, Oliani C and Piccinin GL: L-deprenyl therapy improves verbal memory in amnesic Alzheimer patients. Clin Neuropharmacol 14: 523-536, 1991.

56. Weinreb O, Mandel S, Bar-Am O and Amit T: Iron-chelating backbone coupled with monoamine oxidase inhibitory moiety as novel pluripotential therapeutic agents for Alzheimer's disease: a tribute to Moussa Youdim. J Neural Transm 118: 479-492, 2011.

57. Guay DR: Rasagiline (TVP-1012): a new selective monoamine oxidase inhibitor for Parkinson's disease. Am J Geriat Pharmacother 4: 330-346, 2006.

58. Grünblatt E, Schlösser R, Fischer P, Fischer MO, Li J, Koutsilieri E, Wichart I, Sterba N, Rujescu D, Möller HJ, Adamcyk W, Dittrich B, Müller F, Oberegger K, Gatterer G, Jellinger KJ, Mostafaie N, Jungwirth S, Huber K, Tragl KH, Danielczyk W and Riederer P: Oxidative stress related markers in the 'VITA' and the centenarian projects. Neurobiol Aging 26 429-438, 2005.

59. Wu RM, Mohanakumar KP, Murphy DL and Chiueh CC: Antioxidant mechanism and protection of nigral neurons against $\mathrm{MPP}^{+}$toxicity by deprenyl (selegiline). Ann NY Acad Sci 738: 214-221, 1994

60. Youdim MB, Amit T, Bar-Am O, Weinreb O and Yogev-Falach M: Implications of co-morbidity for etiology and treatment of neurodegenerative diseases with multifunctional neuroprotective-neurorescue drugs; ladostigil. Neurotox Res 10: 181-192, 2006.

61. Bar-Am O, Amit T, Weinreb O, Youdim MB and Mandel S: Propargylamine containing compounds as modulators of proteolytic cleavage of amyloid-beta protein precursor: involvement of MAPK and PKC activation. J Alzheimers Dis 21: 361-371, 2010
62. Weinreb O, Mandel S, Bar-Am O, Yogev-Falach M, Avramovich-Tirosh Y, Amit T and Youdim MB: Multifunctional neuroprotective derivatives of rasagiline as anti-Alzheimer's disease drugs. Neurotherapeutics 6: 163-174, 2009.

63. Weinstock $M$ and Groner E: Rational design of a drug for Alzheimer's disease with cholinesterase inhibitory and neuroprotective activity. Chem Biol Interact 175: 216-221, 2008

64. Youdim MB, Fridkin $M$ and Zheng $\mathrm{H}$ : Bifunctional drug derivatives of MAO-B inhibitor rasagiline and iron chelator VK-28 as a more effective approach to treatment of brain ageing and ageing neurodegenerative diseases. Mech Ageing Dev 126: 317-326, 2005 .

65. Adolfsson R, Gottfries CG, Oreland L, Wiberg A and Winblad B: Increased activity of brain and platelet monoamine oxidase in dementia of Alzheimer type. Life Sci 27: 1029-1034, 1980.

66. Bongioanni P, Gemignani F, Boccardi B, Borgna M and Rossi B: Platelet monoamine oxidase molecular activity in demented patients. Ital J Neurol Sci 18: 151-156, 1997.

67. Ahlskog JE, Uitti RJ, Tyce GM, O'Brien JF, Petersen RC and Kokmen E: Plasma catechols and monoamine oxidase metabolites in untreated Parkinson's and Alzheimer's diseases. J Neurol Sci 136: 162-168, 1996.

68. Konings CH, Scheltens P, Kuiper MA and Wolters EC: No evidence for abnormalities in kinetics of platelet monoamine oxidase in Alzheimer's disease. Clin Chim Acta 240: 99-102, 1995.

69. Winblad B, Gottfries CG, Oreland L and Wiberg A: Monoamine oxidase in platelets and brains of non-psychiatric and non-neurological geriatric patients. Med Biol 57: 129-132, 1979.

70. Mann JJ, Stanley M, Neophytides A, de Leon MJ, Ferris SH and Gershon S: Central amine metabolism in Alzheimer's disease: in vivo relationship to cognitive deficit. Neurobiol Aging 2: 57-60, 1981.

71. da Silva VB, de Andrade P, Kawano DF, Morais PA, de Almeida JR, Carvalho I, Taft CA and da Silva CH: In silico design and search for acetylcholinesterase inhibitors in Alzheimer's disease with a suitable pharmacokinetic profile and low toxicity. Future Med Chem 3: 947-960, 2011.

72. Schneider LS, Severson JA, Chui HC, Pollock VE, Sloane RB and Fredrickson ER: Platelet tritiated imipramine binding and MAO activity in Alzheimer's disease patients with agitation and delusions. Psychiatry Res 25: 311-322, 1988.

73. Rodríguez MJ, Saura J, Billett EE, Finch CC and Mahy N: Cellular localization of monoamine oxidase $\mathrm{A}$ and $\mathrm{B}$ in human tissues outside of the central nervous system. Cell Tissue Res 304: 215-220, 2001

74. Sivasubramaniam SD, Finch CC, Rodriguez MJ, Mahy N and Billett EE: A comparative study of the expression of monoamine oxidase-A and -B mRNA and protein in non-CNS human tissues. Cell Tissue Res 313: 291-300, 2003.

75. Palmer AM and DeKosky ST: Monoamine neurons in aging and Alzheimer's disease. J Neural Transm Gen Sect 91: 135-159, 1993.

76. Reinikainen KJ, Paljärvi L, Halonen T, Malminen O, Kosma VM, Laakso $M$ and Riekkinen PJ: Dopaminergic system and monoamine oxidase-B activity in Alzheimer's disease. Neurobiol Aging 9: 245-252, 1988 .

77. Emilsson L, Saetre P, Balciuniene J, Castensson A, Cairns N and Jazin EE: Increased monoamine oxidase messenger RNA expression levels in frontal cortex of Alzheimer's disease patients. Neurosci Lett 326: 56-60, 2002.

78. Burke WJ,LiSW, Schmitt CA, Xia P, Chung HD and Gillespie KN: Accumulation of 3,4-dihydroxyphenylglycolaldehyde, the neurotoxic monoamine oxidase A metabolite of norepinephrine, in locus ceruleus cell bodies in Alzheimer's disease: mechanism of neuron death. Brain Res 816: 633-637, 1999.

79. Chan-Palay V, Höchli M, Savaskan E and Hungerecker G: Calbindin D-28k and monoamine oxidase A immunoreactive neurons in the nucleus basalis of Meynert in senile dementia of the Alzheimer type and Parkinson's disease. Dementia 4: 1-15, 1993.

80. Barnett JH, Xu K, Heron J, Goldman D and Jones PB: Cognitive effects of genetic variation in monoamine neurotransmitter systems: a population-based study of COMT, MAOA, and 5HTTLPR. Am J Med Genet B Neuropsychiatr Genet 156: 158-167, 2011.

81. Klinteberg B, Levander SE, Oreland L, Asberg M and Schalling D: Neuropsychological correlates of platelet monoamine oxidase (MAO) activity in female and male subjects. Biol Psychol 24: 237-252, 1987. 
82. Heimberg RG, Liebowitz MR, Hope DA, Schneier FR, Holt CS, Welkowitz LA, Juster HR, Campeas R, Bruch MA, Cloitre M, Fallon B and Klein DF: Cognitive behavioral group therapy vs phenelzine therapy for social phobia: 12-week outcome. Arch Gen Psychiatry 55: 1133-1141, 1998.

83. Goldstein DM and Goldberg RL: Monoamine oxidase inhibitor-induced speech blockage. J Clin Psychiatry 47: 604, 1986.

84. Delcker A and Gaertner HJ: Tolerability and antidepressive effect of brofaromine, a short-acting reversible MAO inhibitor - an open study. Eur Neuropsychopharmacol 1: 177-180, 1991.

85. Danilova RA, Mosk vityna TA, Obukhova MF, Belopolskaya MV and Ashmarin IP: Pargyline conjugate-induced long-term activation of monoamine oxidase as an immunological model for depression. Neurochem Res 24: 1147-1151, 1999.

86. Giacobini G, Marchisio PC, Giacobini E and Koslow SH Developmental changes of cholinesterases and monoamine oxidase in chick embryo spinal and sympathetic ganglia. J Neurochem 17: 1177-1185, 1970.

87. Van der Schyf CJ, Gal S, Geldenhuys WJ and Youdim MB: Multifunctional neuroprotective drugs targeting monoamine oxidase inhibition, iron chelation, adenosine receptors, and cholinergic and glutamatergic action for neurodegenerative diseases. Expert Opin Investig Drugs 15: 873-886, 2006

88. Ikemoto K, Kitahama K, Maeda T, Jouvet M and Nagatsu I: Cholinergic neurons with monoamine oxidase type B (MAOB)-activity in the laterodorsal tegmental nucleus of the mouse. Neurosci Lett 271: 53-56, 1999.

89. Nakamura S, Akiguchi I and Kimura J: A subpopulation of mouse striatal cholinergic neurons show monoamine oxidase activity. Neurosci Lett 161: 141-144, 1993.

90.Panagiotidis G, Stenström A and Lundquist I: Effects of adrenergic and cholinergic stimulation on islet monoamine oxidase activity and insulin secretion in the mouse. Eur J Pharmacol 233: 285-290, 1993.

91.Pintar JE, Breakefield XO and Patterson PH: Differences in monoamine oxidase activity between cultured noradrenergic and cholinergic sympathetic neurons. Dev Biol 120: 305-308, 1987.

92. Garrick NA and Murphy DL: Monoamine oxidase type A: differences in selectivity towards l-norepinephrine compared to serotonin. Biochem Pharmacol 31: 4061-4066, 1982.

93. Spector S: Monoamine oxidase in control of brain serotonin and norepinephrine content. Ann NY Acad Sci 107: 856-864, 1963.

94. Kumagae Y, Matsui Y and Iwata N: Deamination of norepinephrine, dopamine, and serotonin by type A monoamine oxidase in discrete regions of the rat brain and inhibition by RS-8359. Jpn J Pharmacol 55: 121-128, 1991.

95. Baron M, Perumal AS, Levitt M and Cannova G: Platelet monoamine oxidase in schizophrenia with beta-phenylethylamine and benzylamine as substrates. Biol Psychiatry 17 479-483, 1982.

96. Lewinsohn R, Glover V and Sandler M: Beta-phenylethylamine and benzylamine as substrates for human monoamine oxidase $\mathrm{A}$ A source of some anomalies? Biochem Pharmacol 29: 777-781, 1980.

97. Moret $\mathrm{C}$ and Briley $\mathrm{M}$ : The importance of norepinephrine in depression. Neuropsychiatr Dis Treat 7 (Suppl 1): 9-13, 2011

98. Levitan MN, Chagas MH, Crippa JA, Manfro GG, Hetem LA, Andrada NC, Salum GA, Isolan L, Ferrari MC and Nardi AE; Brazilian Medical Association: Guidelines of the Brazilian Medical Association for the treatment of social anxiety disorder. Rev Bras Psiquiatr 33: 292-302, 2011 (In Portugese).

99. Schneier FR: Pharmacotherapy of social anxiety disorder. Expert Opin Pharmacother 12: 615-625, 2011.

100.Engelborghs S and De Deyn PP: The neurochemistry of Alzheimer's disease. Acta Neurol Belg 97: 67-84, 1997.

101.Ishrat T, Parveen K, Khan MM, Khuwaja G, Khan MB, Yousuf S, Ahmad A, Shrivastav P and Islam F: Selenium prevents cognitive decline and oxidative damage in rat model of streptozotocin-induced experimental dementia of Alzheimer's type. Brain Res 1281: 117-127, 2009.

102. Schaeffer EL and Gattaz WF: Cholinergic and glutamatergic alterations beginning at the early stages of Alzheimer disease: participation of the phospholipase A2 enzyme. Psychopharmacology (Berl) 198: 1-27, 2008.

103. Tran MH, Yamada K and Nabeshima T: Amyloid beta-peptide induces cholinergic dysfunction and cognitive deficits: a minireview. Peptides 23: 1271-1283, 2002.
104. Dhull DK, Jindal A, Dhull RK, Aggarwal S, Bhateja D and Padi SS: Neuroprotective effect of cyclooxygenase inhibitors in ICV-STZ induced sporadic Alzheimer's disease in rats. J Mol Neurosci 46: 223-235, 2012.

105. McNaull BB, Todd S, McGuinness B and Passmore AP: Inflammation and anti-inflammatory strategies for Alzheimer's disease - a mini-review. Gerontology 56: 3-14, 2010.

106. Cai ZY, Yan Y and Chen R: Minocycline reduces astrocytic reactivation and neuroinflammation in the hippocampus of a vascular cognitive impairment rat model. Neurosci Bull 26: 28-36, 2010

107. Agostinho P, Cunha RA and Oliveira C: Neuroinflammation, oxidative stress and the pathogenesis of Alzheimer's disease. Curr Pharm Des 16: 2766-2778, 2010.

108. Hardy J and Selkoe DJ: The amyloid hypothesis of Alzheimer's disease: progress and problems on the road to therapeutics. Science 297: 353-356, 2002.

109. Song W, Zhou LJ, Zheng SX and Zhu XZ: Amyloid-beta 25-35 peptide induces expression of monoamine oxidase $\mathrm{B}$ in cultured rat astrocytes. Acta Pharmacol Sin 21: 557-563, 2000

110. Carter SF, Schöll M, Almkvist O, Wall A, Engler H, Långström B and Nordberg A: Evidence for astrocytosis in prodromal Alzheimer disease provided by $11 \mathrm{C}$-deuterium-L-deprenyl: a multitracer PET paradigm combining 11C-Pittsburgh compound B and 18F-FDG. J Nucl Med 53: 37-46, 2012.

111. Hu MK, Liao YF, Chen JF, Wang BJ, Tung YT, Lin HC and Lee KP: New 1,2,3,4-tetrahydroisoquinoline derivatives as modulators of proteolytic cleavage of amyloid precursor proteins. Bioorg Med Chem 16: 1957-1965, 2008.

112. Avramovich-Tirosh Y, Amit T, Bar-Am O, Zheng H, Fridkin M and Youdim MB: Therapeutic targets and potential of the novel brain- permeable multifunctional iron chelator-monoamine oxidase inhibitor drug, M-30, for the treatment of Alzheimer's disease. J Neurochem 100: 490-502, 2007.

113. Ono K, Hasegawa K, Naiki H and Yamada M: Anti-Parkinsonian agents have anti-amyloidogenic activity for Alzheimer's beta-amyloid fibrils in vitro. Neurochem Int 48: 275-285, 2006.

114. Yogev-Falach M, Bar-Am O, Amit T, Weinreb $\mathrm{O}$ and Youdim MB: A multifunctional, neuroprotective drug, ladostigil (TV3326), regulates holo-APP translation and processing. FASEB J 20: 2177-2179, 2006

115. Weinreb O, Amit T, Bar-Am O, Sagi Y, Mandel S and Youdim MB: Involvement of multiple survival signal transduction pathways in the neuroprotective, neurorescue and APP processing activity of rasagiline and its propargyl moiety. J Neural Transm Suppl: 457-465, 2006.

116. Zhiyou C, Yong Y, Shanquan S, Jun Z, Liangguo H, Ling Y and Jieying L: Upregulation of BACE1 and beta-amyloid protein mediated by chronic cerebral hypoperfusion contributes to cognitive impairment and pathogenesis of Alzheimer's disease. Neurochem Res 34: 1226-1235, 2009.

117. Liu H, Li Z, Qiu D, Gu Q, Lei Q and Mao L: The inhibitory effects of different curcuminoids on $\beta$-amyloid protein, $\beta$-amyloid precursor protein and $\beta$-site amyloid precursor protein cleaving enzyme 1 in swAPP HEK293 cells. Neurosci Lett 485: 83-88, 2010.

118. Yogev-Falach M, Amit T, Bar-Am O, Weinstock M and Youdim MB: Involvement of MAP kinase in the regulation of amyloid precursor protein processing by novel cholinesterase inhibitors derived from rasagiline. FASEB J 16: 1674-1676, 2002.

119. Youdim MB, Bar Am O, Yogev-Falach M, Weinreb O, Maruyama W, Naoi M and Amit T: Rasagiline: neurodegeneration, neuroprotection, and mitochondrial permeability transition. J Neurosci Res 79: 172-179, 2005.

120. Youdim MB, Amit T, Bar-Am O, Weinstock $M$ and Yogev-Falach M: Amyloid processing and signal transduction properties of antiparkinson-antialzheimer neuroprotective drugs rasagiline and TV3326. Ann NY Acad Sci 993: 378-393, 2003.

121. Kupershmidt L, Amit T, Bar-Am O, Youdim MB and Weinreb O: The novel multi-target iron chelating-radical scavenging compound M30 possesses beneficial effects on major hallmarks of Alzheimer's disease. Antioxid Redox Signal 17: 860-877, 2012.

122. Yang HQ, Sun ZK, Ba MW, Xu J and Xing Y: Involvement of protein trafficking in deprenyl-induced alpha-secretase activity regulation in PC12 cells. Eur J Pharmacol 610: 37-41, 2009.

123. Tsunekawa H, Noda Y, Mouri A, Yoneda F and Nabeshima T: Synergistic effects of selegiline and donepezil on cognitive impairment induced by amyloid beta (25-35). Behav Brain Res 190: 224-232, 2008 
124. Calderón-Garcidueñas L, Kavanaugh M, Block M, D’Angiulli A, Delgado-Chávez R, Torres-Jardón R, González-Maciel A, Reynoso-Robles R, Osnaya N, Villarreal-Calderon R, Guo R, Hua Z, Zhu H, Perry G and Diaz P: Neuroinflammation, hyperphosphorylated tau, diffuse amyloid plaques, and down-regulation of the cellular prion protein in air pollution exposed children and young adults. J Alzheimers Dis 28: 93-107, 2012.

125. Stozicka Z, Zilka N, Novak P, Kovacech B, Bugos O and Novak M: Genetic background modifies neurodegeneration and neuroinflammation driven by misfolded human tau protein in rat model of tauopathy: implication for immunomodulatory approach to Alzheimer's disease. J Neuroinflammation 7: 64, 2010.

126. McGeer EG and McGeer PL: Neuroinflammation in Alzheimer's disease and mild cognitive impairment: a field in its infancy. J Alzheimers Dis 19: 355-361, 2010.

127. Hensley K: Neuroinflammation in Alzheimer's disease: mechanisms, pathologic consequences, and potential for therapeutic manipulation. J Alzheimers Dis 21: 1-14, 2010.

128. Streit WJ: Microglial activation and neuroinflammation in Alzheimer's disease: a critical examination of recent history. Front Aging Neurosci 2: 22, 2010.

129. Saura J, Luque JM, Cesura AM, Da Prada M, Chan-Palay V, Huber G, Löffler J and Richards JG: Increased monoamine oxidase B activity in plaque-associated astrocytes of Alzheimer brains revealed by quantitative enzyme radioautography. Neuroscience 62: 15-30, 1994.

130. Menazza S, Blaauw B, Tiepolo T, Toniolo L, Braghetta P, Spolaore B, Reggiani C, Di Lisa F, Bonaldo P and Canton M: Oxidative stress by monoamine oxidases is causally involved in myofiber damage in muscular dystrophy. Hum Mol Genet 19 $4207-4215,2010$

131.Zheng H, Amit T, Bar-Am O, Fridkin M, Youdim MB and Mandel SA: From anti-Parkinson's drug rasagiline to novel multitarget iron chelators with acetylcholinesterase and monoamine oxidase inhibitory and neuroprotective properties for Alzheimer's disease. J Alzheimers Dis 30: 1-16, 2012.

132.Dimpfel W and Hoffmann JA: Effects of rasagiline, its metabolite aminoindan and selegiline on glutamate receptor mediated signalling in the rat hippocampus slice in vitro. BMC Pharmacol 11: 2, 2011

133. Youdim MB, Maruyama W and Naoi M: Neuropharmacological, neuroprotective and amyloid precursor processing properties of selective MAO-B inhibitor antiparkinsonian drug, rasagiline. Drugs Today (Barc) 41: 369-391, 2005.

134. Weinreb O, Amit T, Bar-Am O and Youdim MB: Ladostigil: a novel multimodal neuroprotective drug with cholinesterase and brain-selective monoamine oxidase inhibitory activities for Alzheimer's disease treatment. Curr Drug Targets 13: 483-494, 2012

135. Weinreb O, Amit T, Bar-Am O and Youdim MB: A novel anti-Alzheimer's disease drug, ladostigil neuroprotective, multimodal brain-selective monoamine oxidase and cholinesterase inhibitor. Int Rev Neurobiol 100: 191-215, 2011.
136. Alafuzoff I, Helisalmi S, Heinonen EH, Reinikainen K, Hallikainen M, Soininen H and Koivisto K: Selegiline treatment and the extent of degenerative changes in brain tissue of patients with Alzheimer's disease. Eur J Clin Pharmacol 55: 815-819, 2000.

137. Birks J and Flicker L: Selegiline for Alzheimer's disease. Cochrane Database Syst Rev: CD000442, 2003.

138. Wilcock GK, Birks J, Whitehead A and Evans SJ: The effect of selegiline in the treatment of people with Alzheimer's disease: a meta-analysis of published trials. Int J Geriatr Psychiatry 17 175-183, 2002.

139. Birks J and Flicker L: Selegiline for Alzheimer's disease. Cochrane Database Syst Rev: CD000442, 2000.

140. Filip V and Kolibás E: Selegiline in the treatment of Alzheimer's disease: a long-term randomized placebo-controlled trial. Czech and Slovak Senile Dementia of Alzheimer Type Study Group. J Psychiatry Neurosci 24: 234-243, 1999.

141. Lawlor BA, Aisen PS, Green C, Fine E and Schmeïdler J: Selegiline in the treatment of behavioural disturbance in Alzheimer's disease. Int J Geriatr Psychiatry 12: 319-322, 1997.

142. Sano M, Ernesto C, Klauber MR, Schafer K, Woodbury P, Thomas R, Grundman M, Growdon J and Thal LJ: Rationale and design of a multicenter study of selegiline and alpha-tocopherol in the treatment of Alzheimer disease using novel clinical outcomes. Alzheimer's Disease Cooperative Study. Alzheimer Dis Assoc Disord 10: 132-140, 1996.

143. Schneider LS, Olin JT and Pawluczyk S: A double-blind crossover pilot study of 1-deprenyl (selegiline) combined with cholinesterase inhibitor in Alzheimer's disease. Am J Psychiatry 150: 321-323, 1993.

144. Youdim MB: The path from anti Parkinson drug selegiline and rasagiline to multifunctional neuroprotective anti Alzheimer drugs ladostigil and m30. Curr Alzheimer Res 3: 541-550, 2006.

145.Zheng H, Fridkin M and Youdim MB: Site-activated chelators derived from anti-Parkinson drug rasagiline as a potential safer and more effective approach to the treatment of Alzheimer's disease. Neurochem Res 35: 2117-2123, 2010.

146. Zheng H, Weiner LM, Bar-Am O, Epsztejn S, Cabantchik ZI, Warshawsky A, Youdim MB and Fridkin M: Design, synthesis, and evaluation of novel bifunctional iron-chelators as potential agents for neuroprotection in Alzheimer's, Parkinson's, and other neurodegenerative diseases. Bioorg Med Chem 13: $773-783,2005$

147. Gökhan-Kelekçi N, Yabanoğlu S, Küpeli E, Salgin U, Ozgen O, Uçar G, Yešilada E, Kendi E, Yešilada A and Bilgin AA: A new therapeutic approach in Alzheimer disease: some novel pyrazole derivatives as dual MAO-B inhibitors and antiinflammatory analgesics. Bioorg Med Chem 15: 5775-5786, 2007.

148. Yamada M and Yasuhara $\mathrm{H}$ : Clinical pharmacology of MAO inhibitors: safety and future. Neurotoxicology 25: 215-221, 2004.

149. Yu PH: Pharmacological and clinical implications of MAO-B inhibitors. Gen Pharmacol 25: 1527-1539, 1994. 